\section{A Comparison of 60-72 Month Old Children's Environmental Awareness and Attitudes: TEMA Kids Program}

\author{
Ayşe Öztürk Samur*
}

\begin{tabular}{ll}
\hline Received: & 12 November 2017 \\
Revised: & 03 January 2018 \\
Accepted: & 07 January 2018 \\
ISSN: $1307-9298$ \\
Copyright (C) IEJEE \\
www.iejee.com
\end{tabular}

DOI: 10.26822/iejee.2018438131

\begin{abstract}
The purpose of this study was to compare children's environmental awareness and attitudes in the classes where TEMA Kids was implemented and where it was not. This study which used pre-test post-test control group quasi-experimental research design was carried out in 2016 -2017 academic year. The study group was composed of 60-72 month old 138 children (69 experimental, 69 control) who continued their preschool education. Environmental awareness and attitude scale for preschool education children was used as data collection tool. The t-test for dependent and independent samples was used to compare children's environmental awareness and attitudes in experimental and control groups. When the findings were examined, it was identified that when compared to the control group, there is a significant difference in favour of children in the classes where TEMA Kids program was implemented in all sub-dimension and total scores of the scale except for the environmental attitude sub-scale protecting creatures sub-dimension.
\end{abstract}

Keywords: Environmental awareness, environmental attitude, TEMA kids educational program, pre-school education

\section{Introduction}

Environmental issues which are fundamental problems of many countries in the world and know no boundaries and ideologies (Kışlalıoğlu, \& Berkes, 2009; Laza, Lotrean, Pintea, \& Zeic, 2009) have reached to important dimensions due to their structural features. The main environmental problems in Turkey are water pollution, air pollution, wastes, noise pollution, and erosion, respectively (Environmental Inspection Report of Turkey, 2017). It is not possible to solve these problems with only technology or regulations because the main source of environmental problems are people with their habits, lifestyles, ideas, beliefs and values and political, economic, and cultural structures created by people. Thus, people's environmental knowledge, their individual attitudes and behaviours towards environment have to change via environmental education (Erten, 2005; Karataş, 2011; Miser, 2010).

Environmental education is defined as the process of understanding of the interrelatedness among people, their culture and their biophysical surroundings, clarifying concepts in order to develop skills and attitudes necessary to understand and appreciate and recognizing values (Palmer, Grodzinska-Jurczak, \& Suggate, 2003). Environmental education implemented with systematic and scientific ways involves environmental knowledge, attitudes towards environment, and good behaviours towards environment (Erten, 2004; Külköylüoğlu, 2000). Individuals gain environmental awareness necessary for making a decision about the subjects related to the environment's quality and developing individual behaviour principles with environmental education. Although environmental awareness is a dynamic structure which develops throughout life, laying the foundation of environmental awareness during the childhood is quite important to display positive attitudes and behaviours towards environment (Türküm, 1998; Wilson, 1996). Thanks to these experiences, children will gain behaviours, skills and values for the natural environment which will continue for a life time (Wilson, 1996).

Environmental education refers to covering a variety of different topics related to the environment in an educational setting (Heimlich, 2002). Environmental education designed for the children aims at providing cultural accumulation and giving information about environment, environmental issues, their solutions, and individual responsibilities (Morgil, Yılmaz, \& Cingör, 2002). Environmental education begins within a family and continues in school. If this training is not provided in the family, the importance of school for this topic increases more (Morgil, Yılmaz, \& Cingör, 2002). Because many families in Turkey are not qualified to train their children about environmental issues, environmental education curricula must be developed beginning from the first stages of basic education (Aktepe, 2005; Şimşekli, 2004; Yücel, \& Morgil, 1998). It is viewed that environmental education programs implemented in the research studies carried out during the early childhood were effective for developing environmental awareness among the children (Ahi, \& Alisinanoğlu, 2016; Carter, 2016; Cevher Kalburan, 2009; Chu et al., 2007; Dilli, \& Bapoğlu Dümenci, 2015; Edwards, \& Cutter-MacKenzie, 2011; Erol, 2016; Gambino, Davis, \& Rowntree, 2009; Hadzigeorgiou, Prevezanou, Kabouropoulou, \& Konsolas, 2011; Inoue, 2015; Kellert, 2005; McClain, \& Vandermaas-Peeler, 2016; Pringle, Hakverdi, Cronin-Jones, \& Johnson, 2003; Shin, 2008; Somerville \& Williams, 2015; Stuhmcke, 2015; Witt, \& Kimple, 2008). Moreover, the research studies reveal that environmental awareness acquired during the pre-school education was effective for developing positive attitudes towards the environment (Eliason, \& Jenkins, 2008; Smith, 2001; Taşkın, \& Şahin, 2008; Wilson, 1996).

In addition to families and educational institutions respon- 
sible for developing environmental awareness, mass media and non-governmental organizations have important roles (Selanik Ay, 2010). It is known that the programs about environment in Western societies are generally successful with the efforts of non-governmental organizations (Tont, 2000). TEMA (The Turkish Foundation for Combating Erosion, Reforestation and the Protection of Natural Habitats) has been carrying out important missions to increase awareness of environmental problems since 1992. As stated in the report of Council for Environmental Education-CEE (2004) decision-makers about the management of the natural assets, non-governmental organizations and educators will play important roles for shaping environment in the future. Educators are responsible for equipping the learners with necessary skills and knowledge so that they can carry out a good assessment over the stimuli in the environment and decision-makers about the natural assets and non-governmental organizations are responsible for providing the necessary technology and knowledge for achieving goals (CEE, 2004). TEMA Kids is a program in which educators and non-governmental organizations come together for the learners in the early childhood period.

TEMA Kids Program developed collaboratively by Turkish Association for Developing Pre-School Education is an education program intended for early childhood period and started piloting in 2010. The aim of this program is to have children raise awareness and develop positive attitudes about topics such as environment, nature, soil, erosion, and sustainable living. The main goal of the TEMA Kids Program which has been carried out since 2010 is to raise environmental awareness with the pre-school children and to create awareness about erosion and soil, one of the aims of TEMA Foundation. The program involves some basic information for teachers about soil, water, and air and 42 activities which will help the program to achieve its goals. One of these activities is called "clean air clean breath". In this activity some pictures depicting air pollution are hung on the walls. Children are asked to examine these pictures and talk about them. A field trip close to highway is held and children make observation, if seasonal conditions are suitable chimney of the houses are also examined. When they come to the classroom they have conversation about their observation and children are asked to draw about their observation on one side of a paper and where they would like to live one the other side of paper. The activity is evaluated with evaluation questions and by giving every child a chance to talk about his picture in front of the group. The activities are implemented by the pre-school teachers/ elementary school teachers. The representatives of TEMA Foundation accept the applications of the schools that volunteer to implement the project and provide the necessary materials to the schools. The volunteer teachers in these schools implement the educational activities in their classes and also demand help from the representatives with such activities as planting saplings, inviting a guest expert and fieldtrip. Teachers choose at least 26 activities out of 42 activities considering the children's age group and adapt the activities considering the region's local characteristics and implement them. The activities were designed and developed regarding the goals and objectives stated in the programs of Ministry of National Education (MEB) Directorate General of Basic Education. The activity form consists of the anticipated outcomes, learning process, materials, new concepts and vocabulary, evaluation of the activity, points to consider when implementing the activities and the extra activities that families can do at home. Moreover, different kinds of activities were recommended to increase the effect of the activities and to achieve different goals. The activities provide opportunities for children to experience life in na- ture and also they are intended for developing their skills like creativity, observation, and critical thinking. After the teachers perform their activities, they can also materialise alternative nature activities according to the children's interests and levels in the groups. The evaluation form for evaluating anticipated outcomes of the children aim at measuring children's level of awareness about the themes studied in the education program. The teachers are expected to fill out this evaluation form for each child at the beginning and at the end of the implementation (TEMA, 2013).

When the literature is reviewed, there is not any research study which examines the effectiveness of TEMA Kids Program which has been implemented with thousands of children since 2010. Within this context, it is considered that the study will make contributions to bridge the gap in literature.

\section{Purpose}

The aim of the study is to examine the effect of TEMA Kids Education Program on 60-72 month old children's environmental awareness and attitudes. The study seeks to answer the following related research questions:

1. Do the pre-test-post-test scores of the children in the experimental and control groups differ at a significant level?

2. Is there a statistically significant difference between the post-test scores which the children in experimental and control groups get from the Environmental Attitude and Awareness Scale?

\section{Method}

The study is a quasi-experimental research that uses pretest post-test control group design. The independent variable of the research is TEMA Kids Education Program and children's environmental awareness and attitudes make up the dependent variable of the research study. Accordingly, experimental and control groups were determined by using purposeful sampling method. The activities prepared by the group teacher according to the outcomes included in the programs of MEB Directorate General of Basic Education were used in both groups but in addition to these activities, TEMA Kids Education Program was implemented with the children in the experimental group throughout the education year. The teachers were set free to choose the program activities. They chose 28 activities and implemented these activities on the day they identified as TEMA kids program day. Each activity lasted between 30 minutes to 95 minutes. Implementing these activities started in September and completed in May.

\section{The study group}

138 children studying in pre-school education institutions in 2016-2017 education year composed the study group. Out of 138 children, 69 children (female $=32$, male $=37$ ) made up the experimental group and 69 (female $=34$, male $=35$ ) of them composed the control group.

Four classes with five year old children in an independent preschool where TEMA kids program was being implemented were identified as experimental group using purposeful sampling method. In this intuition in all classes TEMA kids program was being implemented so another intuition which had at least four classes with five year old children was chosen as control group. Pre-test and posttest couldn't be implemented to all control group and 
Table 1. The pre-test results of the environmental awareness and attitudes scale for pre-school children

\begin{tabular}{lcccrrrrr}
\hline Sub-Scale & Sub-Dimension & \multicolumn{3}{c}{ Experimental Group } & \multicolumn{4}{c}{ Control Group } \\
\hline \multirow{4}{*}{ Awareness } & & $n$ & $M$ & $s d$ & $M$ & $s d$ & $t$ & $p$ \\
\cline { 2 - 9 } & Consumption & 69 & 4.65 & 1.42 & 5.07 & 1.18 & -1.889 & .061 \\
\cline { 2 - 9 } & Protecting Creatures & 69 & 7.75 & 1.87 & 7.81 & 1.70 & -.190 & .849 \\
\cline { 2 - 9 } & Environmental Pollution & 69 & 4.65 & 1.19 & 4.16 & 1.98 & 1.772 & .079 \\
\cline { 2 - 9 } & Awareness Total & 69 & 17.05 & 2.75 & 17.04 & 3.49 & .027 & .978 \\
\hline \multirow{3}{*}{ Attitude } & Consumption & 69 & 8.57 & 1.37 & 8.94 & 1.53 & -1.524 & .130 \\
\cline { 2 - 9 } & Protecting Creatures & 69 & 6.92 & 1.34 & 7.26 & 3.76 & -.694 & .489 \\
\cline { 2 - 9 } & Environmental Pollution & 69 & 8.32 & 1.60 & 8.51 & 1.24 & -.771 & .442 \\
\cline { 2 - 9 } & Attitude Total & 69 & 23.81 & 3.38 & 24.71 & 4.42 & -1.341 & .182 \\
\hline Total & & 69 & 40.86 & 5.05 & 41.75 & 6.44 & .898 & .371 \\
\hline
\end{tabular}

experimental group children $(n=200)$, because of different reasons such as absenteeism on the day test were implemented leaving school, unwilling to participate etc., so 138 children were included in the study. The independent t-test (for unrelated groups) was used to examine whether or not there was a statistically significant difference between experimental and control group children's pre-test scores from the "the Environmental Attitude and Awareness Scale for Pre-School Children" and the analysis results were presented in Table 1 .

Table 1 presents that there is not a significant difference between the pre-test scores of the children in experimental and control groups from the Environmental Awareness and Attitudes Scale. It can be stated in line with this finding that children in both groups exhibit similar qualities in terms of environmental awareness and attitudes.

\section{Data collection tools}

Environmental awareness and attitude scale for pre-school children. "Environmental Awareness and Attitudes Scale for Pre-school Children" developed by Büyüktaşkapu Soydan and Öztürk Samur to determine the children's environmental awareness and attitudes towards environment was used in the study. The scale consists of two sub-scales, Environmental Awareness (12 items) and Environmental Attitudes (14 items), and total 26 items with pictures. Both sub-scales are composed of sub-factors of consumption, protecting creatures, and environmental pollution. Environmental Awareness sub-scale explains 40.94\% of the total variance and Environmental Attitudes sub-scale explains $44.02 \%$ of the total variance. The factor loadings of the items in the Environmental Awareness sub-scale change between .39-.74 and .42-.74 for Environmental Attitudes sub-scale. The correlation coefficient between factors related to the children's Environmental Awareness sub-scale (consumption, protecting creatures, and environmental pollution), are $r=.80, .78$ and $.83 \mathrm{re}$ spectively. The correlation coefficient between factors related to the children's Environmental Attitudes sub-scale (consumption, protecting creatures, and environmental pollution), are $r=.70, .79$ and .72 respectively. The statistics performed for the reliability reveals that Sperman Brown reliability coefficient for Environmental Awareness sub-scale was calculated as .65 and Cronbach Alpha reliability coefficient was calculated as .66. Sperman Brown reliability coefficient was calculated as .75 and Cronbach Alpha reliability coefficient was calculated as .73 for Environmental Attitudes sub-scale. Sperman Brown reliability coefficient was calculated as .60 and Cronbach Alpha reliability coefficient as .67 for the whole scale. According to the t-test results which were carried out to determine the distinctiveness of the scale related to the significance of the difference between lower $27 \%$ and upper $27 \%$, there was a significant difference in favour of upper group. The scale's item distinctiveness power change between .32 and .40 for Environmental Awareness sub-scale and between .34 and .47 for Environmental Attitudes sub-scale. The scale's mean item distinctiveness power is .38 (Büyüktaşkapu Soydan \& Öztürk Samur, 2017).

\section{Data collection and analysis}

Before the data collection, the staff and the headmasters of the schools were informed about the aim of the study. Then, Environmental Awareness and Attitude Scale for Pre-school Children scale was administered to the children individually in a quiet place in their school by the researcher. It took about 15 minutes to administer the test to each child. After ensuring that the children understand the question type with a sample item, the rest of the items in the scale were asked one at a time.

The dependent t-test (for related groups) was used to compare the children's pre-test post-test average point scores in experimental and control groups. The independent t-test was (for unrelated groups) performed to compare average post-test scores of the children in experimental and control groups.

\section{Findings}

The t-test results for dependent samples related to the pre-test and post-test scores of the children in experimental and control groups were presented in Table 2.

When Table 2 was examined, it was found that there was not a significant difference with the average pretest post-test scores of the children in the experimental group in terms of protecting creatures sub-dimension of environmental awareness sub-scale $(t=.832, p>.05)$ and consumption sub- dimension of attitude scale $(t=-1.805$, $p>.05)$ but there was a significant difference with all other sub-dimensions. When the average point scores of the children in the control group were examined, it was determined that there was not a significant difference considering the protecting creatures sub-dimension of environmental awareness sub-scale $(t=-.199, p>.05)$, consumption $(t=-4.414, p>.05)$ and protecting creatures $(t=$ $-1.035, p>.05)$ sub-dimensions of attitude scale but there was a significant difference with all other sub-dimensions.

The independent t-test related to post-test scores of the children in the experimental and control groups were presented in Table 3. 
Table 2. The t-test for dependent samples related to the Environmental Awareness and Attitude Scale for Preschool Children (EAASPC) scores of the children in experimental and control groups

\begin{tabular}{|c|c|c|c|c|c|c|c|c|c|c|c|}
\hline \multirow[t]{2}{*}{ Sub-Scale } & \multirow[t]{2}{*}{$\begin{array}{c}\text { Sub- } \\
\text { Dimension }\end{array}$} & \multicolumn{6}{|c|}{ Experimental Group } & \multicolumn{4}{|c|}{ Control Group } \\
\hline & & & $n$ & $M$ & $s d$ & $t$ & $p$ & $M$ & $s d$ & $t$ & $p$ \\
\hline \multirow{8}{*}{ Awareness } & \multirow{2}{*}{ Consumption } & Pretest & 69 & 4.65 & 1.42 & -19.367 & $.00 *$ & 5.07 & 1.18 & -25.285 & $.00 *$ \\
\hline & & Posttest & 69 & 9.64 & 1.26 & & & 8.94 & 1.11 & & \\
\hline & \multirow{2}{*}{$\begin{array}{l}\text { Protecting } \\
\text { Creatures }\end{array}$} & Pretest & 69 & 7.75 & 1.88 & .832 & .40 & 7.81 & 1.70 & -.199 & .84 \\
\hline & & Posttest & 69 & 7.86 & 1.15 & & & 7.52 & .65 & & \\
\hline & \multirow{2}{*}{$\begin{array}{l}\text { Environmental } \\
\text { Pollution }\end{array}$} & Pretest & 69 & 4.65 & 1.20 & -19.290 & $.00 *$ & 4.16 & 1.98 & -20.040 & $.00 *$ \\
\hline & & Posttest & 69 & 9.52 & 1.19 & & & 9.01 & .81 & & \\
\hline & \multirow{2}{*}{$\begin{array}{c}\text { Awareness } \\
\text { Total }\end{array}$} & Pretest & 69 & 17.05 & 2.75 & -16.730 & $.00 *$ & 17.04 & 3.49 & -22.071 & $.00 *$ \\
\hline & & Posttest & 69 & 27.02 & 2.78 & & & 25.47 & 1.94 & & \\
\hline \multirow{8}{*}{ Attitude } & \multirow{2}{*}{ Consumption } & Pretest & 69 & 8.57 & 1.37 & -1.805 & .07 & 8.94 & 1.53 & -4.414 & .08 \\
\hline & & Posttest & 69 & 9.58 & 1.27 & & & 8.96 & 1.19 & & \\
\hline & \multirow{2}{*}{$\begin{array}{l}\text { Protecting } \\
\text { Creatures }\end{array}$} & Pretest & 69 & 6.92 & 1.34 & -2.740 & $.00 *$ & 7.26 & 3.76 & -1.035 & .30 \\
\hline & & Posttest & 69 & 7.72 & 1.14 & & & 7.52 & .75 & & \\
\hline & \multirow{2}{*}{$\begin{array}{l}\text { Environmental } \\
\text { Pollution }\end{array}$} & Pretest & 69 & 8.32 & 1.62 & -2.996 & $.00 *$ & 8.51 & 1.24 & -7.285 & $.00 *$ \\
\hline & & Posttest & 69 & 9.52 & 1.20 & & & 9.01 & .815 & & \\
\hline & \multirow{2}{*}{ Attitude Total } & Pretest & 69 & 23.81 & 3.38 & -3.335 & $.00 *$ & 24.71 & 4.42 & -3.967 & $.00 *$ \\
\hline & & Posttest & 69 & 26.82 & 2.78 & & & 25.49 & 1.94 & & \\
\hline \multirow{2}{*}{ Total } & & Pretest & 69 & 40.86 & 5.05 & -11.144 & $.00 *$ & 41.75 & 6.44 & -14.850 & $.00 *$ \\
\hline & & Posttest & 69 & 53.84 & 5.56 & & & 50.96 & 3.88 & & \\
\hline
\end{tabular}

Table 3. The independent t-test related to Environmental Awareness and Attitude Scale for Preschool Children (EAASPC) posttest scores of the children in the experimental and control groups

\begin{tabular}{|c|c|c|c|c|c|c|c|c|}
\hline Sub-Scale & Sub-Dimension & \multicolumn{3}{|c|}{ Experimental Group } & \multicolumn{4}{|c|}{ Control Group } \\
\hline \multirow{3}{*}{ Awareness } & Consumption & 69 & 9.64 & 1.11 & 8.94 & 1.25 & -3.442 & $.00 *$ \\
\hline & Protecting Creatures & 69 & 7.86 & .64 & 7.52 & 1.14 & -2.104 & $.03 *$ \\
\hline & Environmental Pollution & 69 & 9.52 & .81 & 9.01 & 1.19 & -2.914 & $.00 *$ \\
\hline \multirow{3}{*}{ Attitude } & Protecting Creatures & 69 & 7.72 & .74 & 7.52 & 1.14 & -1.233 & .22 \\
\hline & Environmental Pollution & 69 & 9.52 & .81 & 9.01 & 1.20 & -2.891 & $.00 *$ \\
\hline & Attitude Total & 69 & 26.82 & 1.93 & 25.49 & 2.77 & -3.339 & $.00 *$ \\
\hline
\end{tabular}

As seen in Table 3, when the post-test point scores of the children in the experimental and control groups were examined, it was found that the experimental group's average sub-dimension scores, total average sub-scale scores, and total average scale scores were higher than the average control group scores. When compared statistically, it was found that except for the protecting creatures sub-dimension of attitude scale $(t=-1.233, p>.05)$, this difference was meaningful for the other total average sub-dimension, sub-scale average point scores.

\section{Results and Discussion}

In this study which was conducted in order to find out the effect of TEMA Kids Education Program on 60-72 month old children's environmental awareness and attitudes, it was revealed that there was not a significant difference with the protecting creatures' sub-dimension of environmental awareness sub-scale and consumption sub-dimension of attitude sub-scale of the children in the experimental group but there was a significant difference with all of the other sub-dimensions in favour of post-test average scores. When the average point scores of the children in control groups were examined, it was determined that that there was not a significant difference with protecting creatures sub-dimension of environmental awareness and attitudes sub-scale and consumption sub-dimension of attitude sub-scale; however, there was a significant difference with all of the other sub-dimensions in favour of post-test average scores. Considering this result, it can be stated that both the activities included in pre-school education program and TEMA Kids Education Program had effects on children's environmental awareness environmental attitudes except for having children raise awareness regarding protecting creatures and increasing attitudes towards consumption.

In addition to this, when the post-test scores of the children in experimental and control groups were examined, it was revealed that there was a significant difference in favour of experimental group regarding all of the other total average sub-dimension, sub-scale average point scores 
except for the protecting creatures sub-dimension of attitude sub-scale. This result exhibits that TEMA Kids Education Program was more effective on children's environmental awareness and attitudes. In accordance with the current study a number of studies carried out also revealed that environmental education programs implemented within the framework of specific education programs during the early childhood period were more effective (Ahi, \& Alisinanoğlu, 2016; Carter, 2016; Cevher Kalburan, 2009; Chu et al., 2007; Dilli, \& Bapoğlu Dümenci, 2015; Edwards, \& Cutter-MacKenzie, 2011; Erol, 2016; Gambino, Davis, \& Rowntree, 2009; Hadzigeorgiou, Prevezanou, Kabouropoulou, \& Konsolas, 2011; Inoue, 2015; McClain, \& Vandermaas-Peeler, 2016; Pringle, Hakverdi, Cronin-Jones, \& Johnson, 2003; Shin, 2008; Somerville \& Williams, 2015; Stuhmcke, 2015; Witt, \& Kimple, 2008).

One of the interesting results in the research study is that there was not a significant difference between the posttest scores of the children in experimental and control groups regarding protecting creatures sub-dimension of attitude sub-scale. In addition, it was observed that there was not a significant difference with the pre-test scores of the children in control group regarding protecting creatures sub-dimension included in awareness and attitude sub-scales but there was a significant difference only with children's attitude sub-scale scores in experimental group. Moreover, pre-test post-test scores of the children in both groups regarding consumption in attitude sub-scale did not differ. These results reveal that there is need for implementation of much more effective programs about protecting creatures and consumption to raise environmental awareness and improve attitudes.

A good environmental education for early childhood period must include a content related to real-life experiences, interactions with different disciplines, and communication with the children (Basile \& White, 2000). The teacher must focus on experience more than teaching, he must show children his interest in environment and he must be a role-model about protecting the environment (Wilson, 1996). Environmental education must begin with simple experiences and children should have positive experiences in open spaces. Although TEMA Kids Education Program involves activities performed in nature, the children's interaction with nature in this process include a short and controlled period of time. Nowadays, children in many countries have a problem that play less in a limited space and in limited time unfortunately. They do not have opportunities to manipulate the environment creatively. In place of this, they spend much more time at home and they are engaged in pre-programmed activities under the supervision of an adult (Louv, 2010; McCans, 2004; Memik, 2004; Prezza, Alparone, Cristallo, \& Luigi, 2005; Witten, Kearns, Carrol, Asiasiga, \& Tavae, 2013; Turgut, \& Yılmaz, 2010). Because the natural environment where children can play freely diminish gradually and children have limited time to spend and play freely outdoors (McCans, 2004), they cause children to be condemned to indoor settings. The children who live in urban areas and have an opportunity to play outdoors usually spend their time in supervised outdoor spaces under the intensive supervision of adults against physical dangers and security (Harden, 2000; Backett-Milburn, \& Harden, 2004). In this context, the reasons for the inefficiency of TEMA Kids Education Program regarding protecting creatures sub-dimension is that children spend less time in nature, they cannot form an interaction with nature, and the possibility of children's interaction with the creatures gradually decreases. In addition to that, it is required that young children must observe similar behaviours in their family settings and have an opportunity to practise them so that the attitudes and behaviours they acquire via education at school become permanent. Because of that, it is very important that families must be included in the environment education programs developed for the children in early childhood classes. Thus, children will acquire permanent and positive attitudes and behaviours towards environment and also the training of adults who have more effects on environmental problems will be realized (Soydan, \& Öztürk Samur, 2014). The research studies reveal that the families who are actively engaged in studies related to the environment encourage their kids (Chawla, \& Cushing, 2007) and the family involvement and participation in environmental education programs are considerably effective (Erol, 2016). Thus, students, families, or community members must actively participate in educational environment programs to experience and learn the environment (Ballantyne, Connell, \& Fien, 1998). Educational environment carried out with the family involvement in a time period out of school time can enable children to create a bond with the environment and develop positive attitudes towards the environment. Effective environmental education programs are very much interested in children's and teenagers' daily life and what they do in their own backyards (Ballantyne, \& Packer, 2009). The activities carried out in nature during the childhood (games, walking, camping, climbing and etc.) affect the families, teachers, and the other role models' attitudes as well as children's behaviours towards the environment (Chawla, \& Cushing, 2007). TEMA Kids Education Program offers activities for parental involvement to carry out with their children as suggestions but they are not obliged to do them. The undifferentiated scores at pre-test post-test for consumption in attitude sub-scale of the children in both groups can be due to non-involvement of the parents in the education program. Previous studies in the literature have shown that family is the most important factor in identifying children's consumption attitudes (Ateşoğlu \& Türkkahraman, 2009; Ersoy, \& Sarıabdullaoğlu, 2010; Kocakurt, \& Güven, 2005; Lueg \& Finney, 2007; Madran \& Bozyiğit, 2013).

Pre-school environmental education can be carried out anywhere in which a child interacts with nature. However, this education must continue in both family and school life without being interrupted and a child should often be offered opportunities to have positive experiences with nature. A child who grows up in the natural world and has a regular relationship with it is expected to develop positive attitudes towards creatures and change his consumption habits to promote the conservation of nature. Thus, while teachers design and plan their activities, they must involve parents in the education program and children's interaction with nature should be supported by including education that is given in nature.

\section{References}

Ahi, B., \& Alisinanoğlu, F. (2016). Okul öncesi eğitim programına kaynaştırılan çevre eğitimi programının çocukların çevre kavramı hakkındakı zihinsel model gelişimine etkisi. Kafkas Üniversitesi Sosyal Bilimler Enstitüsü Dergisi, 18, 305-329.

Aktepe, S. (2005). Illköğretim okullarında çevre eğitimi (Eko-okulların ve diğer okulların karșılaștırılması). Yayınlanmamış yüksek lisans tezi. Gazi Üniversitesi, Ankara.

Ateşoğlu, I.., Türkkahraman, M. (2009). Çocukların tüketici olarak sosyalleşmesi. Süleyman Demirel Üniversitesi iktisadi ve Idari Bilimler Fakültesi Dergisi, 14(3), 215228. 
Backett-Milburn K, \& Harden J. (2004). How children and their families construct and negotiate risk, safety and danger. Childhood, 11, 429-447.

Ballantyne, R., Connell, S., \& Fien, J. (1998). Students as catalysts of environmental change: A framework for researching intergenerational influence through environmental education. Environmental Education Research, 4(3), 285-298.

Ballantyne, R., \& Packer, J. (2009). Introducing a fifth pedagogy: Experience-based strategies for facilitating learning in natural environments. Environmental Education Research, 15(2), 243-262.

Basile, C. G., \& White, C. (2000). Respecting living thinks: Environmental literacy for young children. Early Childhood Education Journal, 28(1), 57-61.

Büyüktaşkapu Soydan, S., \& Öztürk Samur, A. (2017). Validity and reliability study of environmental awareness and attitude scale for preschool children. International Electronic Journal of Environmental Education, 7(1), 78-96.

Carter, D. A. (2016). Nature-based social-emotional approach to supporting young children's holistic development in classrooms with and without walls: The social-emotional and environmental education development (SEED) framework. International Journal of Early Childhood, 4(1), 10.

Cevher Kalburan, F. N. (2009). Çocuklar için çevresel tutum ölçeği ile yeni ekolojik paradigma ölçeğinin geçerlik güvenirlik çalışması ve çevre eğitim programının etkisinin incelenmesi. Yayınlanmamış doktora tezi. Gazi Üniversitesi, Ankara.

Chawla, L., \& Cushing, D.F., (2007). Education for strategic environmental behaviour. Environmental Education Research, 13(4), 437-452.

Chu, H. E., Lee, E. A., Ko, H. R., Shin, D. H., Lee, M. N., Min, B. M., \& Kang, K. H. (2007). Korean year 3 children's environmental literacy: A prerequisite for a Korean environmental education curriculum. International Journal of Science Education, 29(6), 731-746.

Council for Environmental Education-CEE (2004). Project wild $K-12$ curriculum \& activity guide. TX, USA.

Dilli, R., \& Bapoğlu Dümenci, S. (2015). Okul öncesi dönemi çocuklarına Anadolu'da yaşamış nesli tükenmiş hayvanların öğretilmesinde müze eğitiminin etkisi. Eğitim ve Bilim, 40(181), 217-230.

Edwards, S., \& Cutter-MacKenzie, A.N. (2011). Environmentalising early childhood education curriculum through pedagogies of play. Australian Journal of Early Childhood, 36(1), 51-59.

Eliason, C. \& Jenkins, L. (2008). A practical guide to early childhood curriculum (8th Edition). New Jersey: Merrill Prentice Hall.

Environmental Inspection Report of Turkey (2017). Directorate general of environmental impact assessment, permit and inspection. Ankara, Turkey.

Erol, A. (2016). Proje yaklaşımına dayanan aile katııımlı çevre eğitimi programının 5-6 yaş çocuklarının çevreye yönelik farkındalık ve tutumlarına etkisinin incelen- mesi. Yayınlanmamış yüksek lisans tezi. Pamukkale Üniversitesi Eğitim Bilimleri Enstitüsü, Denizli.

Ersoy, A. F., \& Sarıabdullahoğlu, A. (2010). Erken dönemde tüketici bilincinin geliştirilmesi. Üçüncü Sektör Kooperatifçilik, 45(1), 65-76.

Erten, S. (2004). Çevre eğitimi ve çevre bilinci nedir, çevre eğitimi nasıl olmalıdır?, Çevre ve Insan Dergisi, Çevre ve Orman Bakanlığı Yayın Organı. Sayı 65/66.

Erten, S. (2005). Okul öncesi öğretmen adaylarında çevre dostu davranışların araştırılması. Hacettepe Üniversitesi Eğitim Fakültesi Dergisi, 28, 91-100.

Gambino, A., Davis, J., \& Rowntree, N. (2009). Young children learning for the environment: Researching a forest adventure. Australian Journal of Environmental Education, 25, 83-94.

Hadzigeorgiou, Y., Prevezanou, B., Kabouropoulou, M., \& Konsolas, M. (2011). Teaching about the importance of trees: A study with young children. Environmental Education Research, 17(4), 519-536.

Harden, J. (2000). There's no place like home: The public/ private distinction in children's theorizing of risk and safety. Childhood, 7(1), 43-59.

Heimlich, J. E. (2002). Environmental education: A resource handbook. Phi Delta Kappa Educational Foundation, Bloomington.

Inoue, M. (2015). Beyond traditional nature-based activities to education for sustainability: A case study from Japan. In J. Davis (Ed.), Young children and the environment: Early education for sustainability (pp. 266-277). Cambridge University Press, London.

Karataş, A. (2011). Çevre bilincinin geliștirilmesinde doğa tarihi müzelerinin rolü. Akademik Bakış Dergisi, 27, 1-15.

Kellert, S. R. (2005). Building for life: Designing and understanding the human-nature connection (2nd Ed.). Washington, DC: Island Press.

Kışlalığlu, M., \& Berkes, F. (2009). Çevre ve ekoloji (11. basım). İstanbul: Remzi Kitabevi.

Kocakurt, Ö., \& Güven, S. (2005). Çevre, aile ve çocuk, Eğjtim ve Bilim Dergisi, 30, 34-38.

Külköylüoğlu, O. (2000). Çevre eğitiminde yapısal unsurlar ve amaçlar, üniversitelerin eğitimdeki önemi. Uluslararası ekoloji ve çevre sorunları sempozyumu, Çevre Bakanlığı Yayını, Ankara.

Laza, K. V., Lotrean, L., Pintea, A., \& Zeic, A. (2009). Environmental risk perception, attitudes, and behaviors and educational strategies to shape friendly environmentally behavior. Proceedings of the 5th WSEAS/ IASME International Conference on Educational Technologies, 110-116.

Louv, R. (2010). Doğadaki son çocuk. (Çev. C. Temürcü). Ankara: TÜBITAK.(Original Title: Last child in the wood).

Lueg, J. E., \& Finney, R. Z. (2007). Interpersonal communication in the consumer socialization process: scale- 
development and validation, Journal of Marketing Theory and Practice, 15(1), 25-39.

Madran, C., \& Bozyiğit, S. (2013). Çocukların tüketici olarak sosyalleşme süreci. Çağ University Journal of Social Sciences, 10(1), 71-95.

McCans, S.E. (2004). Wild places: An exploration of mothers' attitudes and beliefs regarding risk in outdoor play settings. MA Thesis. The University of Guelph, Kanada.

McClain, C., \& Vandermaas-Peeler, M. (2016). Outdoor explorations with preschoolers: An observational study of young children's developing relationship with the natural world. International Journal of Early Childhood, 4(1), 38-54.

Memik, N. H. (2004). An evaluation of the changing approaches to children's play spaces. Yayınlanmamış Yüksek Lisans Tezi. Orta Doğu Teknik Üniversitesi, Ankara.

Miser, R. (2010). Çevre eğitimi. Ankara Üniversitesi Eğitim Bilimleri Fakültesi Mezunları Derneği Yayınları, Ankara.

Morgil, ì., Yılmaz, A., \& Cingör, N. (2002). Fen eğitiminde çevre ve çevre koruma projesi hazırlanmasına yönelik çalışma. V. Ulusal Fen bilimleri ve Matematik Eğitimi Kongresi Bildiriler Kitabı, 45.

Palmer, J.A., Grodzinska-Jurczak, M., \& Suggate J. (2003). Thinking about waste: Development of English and Polish children's understanding of concepts related to waste management. European Early Childhood Education Research Journal, 11(2), 117-139.

Prezza, M., Alparone, F., Cristallo, C., \& Luigi, S. (2005). Parental perception of social risk and of positive potentiality of outdoor autonomy for children: the development of two instruments. Journal of Environmental Psychology, 25(4), 437-453.

Pringle, R., Hakverdi, M., Cronin-Jones, L., \& Johnson, C. (2003). Zoo school for preschoolers: Laying the foundation for environmental education. Annual meeting of the American educational research association. (ERIC Document Reproduction Service No.ED475663), Chicago, IL.

Selanik Ay, T. (2010). Sosyal bilgiler dersinde çevre bilinci kazandırmada medya ürünlerinden yararlanmaya ilişkin öğrenci görüşleri. Uluslararası Avrasya Sosyal Bilimler Dergisi, 1(1), 76-93.

Shin, K. H. (2008). Development of environmental education in the Korean kindergarten context. Unpublished doctoral dissertation. University of Victoria, Canada.

Smith, A. (2001). Early childhood a wonderful time for science learning. Australian Primary and Junior Science Journal, 17(2), 18-20.

Somerville, M., \& Williams, C. (2015). Sustainability education in early childhood: An updated review of research in the field. Contemporary Issues in Early Childhood, 16(2), 102-117.

Soydan, S., \& Öztürk Samur, A. (2014). A comparative study on the environmental attitudes of 6066 month old children and their mothers. Mevlana International Journal of Education (MIJE), 4(2), 27-36.

Stuhmcke, S. M. (2015). The children's environment project: Developing a transformative project approach with children in a kindergarten. In J. Davis (Ed.) Young children and the environment: Early education for sustainability (pp. 225-248). Cambridge University Press, London.

Şimşekli, Y. (2004). Çevre bilincinin geliştirilmesine yönelik çevre eğitimi etkinliklerine ilköğretim okullarının duyarlılı̆ıı, Uludağ Üniversitesi Eğitim Fakültesi Dergisi, XVII(1), 83-92.

Taşkın, Ö., \& Şahin, B. (2008). Çevre kavramı ve altı yaş okul öncesi çocukları. Pamukkale Üniversitesi Eğitim Fakültesi Dergisi, 23(23), 1-12.

TEMA (2013). Minik TEMA Eğitim Programı Kitabı. TEMA Vakfı Yayınları, İstanbul.

Tont, S. (2000). Batılı ülkelerde kurtarıcı çevreciliğin kronolojisi. Türkiye'de Çevrenin ve Çevre Korumanın Tarihi Sempozyumu, İstanbul.

Turgut, H., \& Yılmaz, S. (2010). Ekoloji temelli çocuk oyun alanlarının oluşturulması. Ulusal Karadeniz Ormancılık Kongresi Kitabı, IV, 1618-1630.

Türküm, A.S. (1998). Çağdaş toplumda çevre sorunları ve çevre bilinci. İçinde G. Can (Ed). Çağdaş yaşam çağdaş insan. Anadolu Üniversitesi Açık Öğretim Fakültesi Illköğretim Öğretmenliği Lisans Tamamlama Programı, Eskişehir, 165-181.

Wilson, R.A. (1996). Starting early: Environmental education during the early childhood years. Columbus: Clearinghouse for Science Mathematics and Environmental Education (ERIC Document Reproduction Service No. ED402147).

Witt, S., \& K. Kimple. (2008). How does your garden grow? Teaching preschool children about the environment. Early Child Development and Care, 178, 41-8.

Witten, K., Kearns, R., Carroll, P., Asiasiga, L., \& Tavae, N. (2013). New Zealand parents' understandings of the intergenerational decline in children's independent outdoor play and active travel. Children's Geographies, 11(2), 215-229.

Yücel, S. A., \& Morgil, İ. (1998). Yükseköğretimde çevre olgusunun araştırılması, Hacettepe Üniversitesi Eğitim Fakültesi Dergisi, 14, 84-91. 